\title{
Motive on playing online game as predictor of adolescence's problematic online gaming use in makassar
}

\author{
Dewi Fatmasari Edy \\ Department of Psychology \\ Medical Faculty \\ Hasanuddin University \\ Makassar, Indonesia \\ dewifatmasariedy@gmail.com
}

\author{
Elvita Bellani \\ Department of Psychology \\ Hasanuddin University \\ Makassar, Indonesia
}

\author{
Mayenrisari Arifin \\ Department of Psychology \\ Hasanuddin University \\ Makassar, Indonesia
}

\begin{abstract}
Online gaming may cause deficit on adolescence's academicals achievement and social interaction difficulties, thus may be referred as one of a social deviance. Deviation is a set of behavior which able to bring up problematic on daily life. One of the factors that contribute on deviation is individual motive. Motive can be assumed as an energy that may determine one's behavior.

Motives on online gaming could be the predictor of deviation on online gaming. Deviation on online gaming can be referred as problematic online gaming use. This study aims to find our problematic online gaming use on adolescence as well as motives on online gaming that may predict problematic online gaming use. The method of this study is quantitative research method.

Motives for Online Gaming Questionnaire and Problematic Online Gaming Questionnaire measured 301 participants in total. The findings show that tendency on adolescence's problematic online gaming use are on moderate category. By multiple regression can be seen that motives on online gaming simultaneously significant predicting adolescence's problematic online gaming use, which the contribution online gaming motives are account for 51,6 percent. While social motive, escape motive, competition motive, skill development motive, and fantasy motive partially significant predicting problematic online gaminguse. Coping motive and recreation motive partially not significant predicting problematic online gaming use.
\end{abstract}

Keywords-playing online games motive; problematic online gaming us; adolescence.

\section{INTRODUCTION}

Adolescence as young generation should be prepared and preparing their self to contribute on their nation's development. This statement based in the adolescence stage, which is the crisis age on academic aspect [1]. Social and academicals pressure makes the adolescence have more responsibility on academicals aspect. Therefore, adolescence whose age is in school age should prioritize study as their main activity [1].

Study as the main activity unfortunately does not occurred on some adolescence. Adolescence mostly spend their time on playing video games, therefore, other of their activity will decrease even affecting on their adult age [2]. Anand also mentioned that the increasing of video game playing time could affect on drop the academicals performance [3]. Another effect of video game addiction is inclination of individual psychological and social stress [4].

Game online would have bad influence, but at another side it is needed to fulfill someone's need of entertainment. Therefore, it should be considered first on players characteristic from motivational perspective by exploring the need and motives behind it without take concern on the beneficial or the negativity for someone [5]. This motive may be considered as energy and could be the determinant factor of someone's behavior.

The previous research shows that motive is a determinant factor of someone's behavior. It shows that in drug taking behavior, the motive mediates other determinant factor of this behavior, such as personality and hope [6] [7]. Personality and other determinant aspects could determine behavior by motive mediation that motivates someone. Motive on online gaming is as important to be concerned. Thus, motive on online gaming may be the predictor of problematic online gaming use [5].

There seem to be a tendency that adolescence neglects their main task as a student. By this statement, in issue arise on gap of online gaming use. This is important to be considered since adolescence is a crisis age that can affect on their success in the future. Therefore, this study would like to know the motives on adolescence online gaming that can cause problematic online gaming.

This study aims to know the illustration of adolescence's problematic online gaming use and understanding the motives that can predict problematic online gaming use. The theoretical advantages of this research is to expand the field of psychological study especially on developmental psychology and clinical psychology about problematic online gaming use adolescence and could be a literature review which is 
beneficial for the readers that are interested in online gaming study. The practical advantages of this study is to give information for parents and social environment to guide the development of adolescence, informing that it is important to create a psycho education to prevent game online player to be problematic online gaming. Furthermore, adolescence should understand to use the game online facilitation as an entertaining media. This understanding is very crucial so that adolescence will not have severe problem. Thus, adolescence could optimize their capacity as a generation that contributes on national development.

\section{LITERATURE REVIEW}

\section{A. Problematic Online Gaming Use}

Person who plays game online intensely and thinks that game online is not only as entertaining media can be seen from their tendency on problematic online game. Problematic online gaming use (POGU). It is an issue, which related significance on online game playing, especially on adolescence and young adult [2]. Problematic online gaming as an overusing and may disrupt individual daily life [8]. Some factor that cause someone have problematic online gaming usemay vary, such as social economic [9], gender [10] [11] [12], attraction disturbance [13], stress coping [13] [14], less social support [13], need fulfillment [15].

Papay, et al. [16] mentioned individual problem related to online gaming as problematic online gaming use. Problematic online gaming use can be seen from fulfillment of some criteria, which is preoccupation, immersion, withdrawal, overuse, interpersonal conflict, andsocial isolation.

\section{B. Playing Online Games Motive}

The attraction of game online is at the potency of game online on fulfilling the psychological need, which can be conceptualized as motive on online gaming [17]. Every human has different motive as a factor that cause him or her to play online game. Motive be a crucial aspect to understand the nature of online gamer. Motive can be seen as a basic component from a form of motivation to play [5].

Demetrovics, et al. [5] find out the motives on online gaming, which is: social, escape, competition, coping, skill development, fantasy, and recreation. Those seven motives were arising from the findings of study that had been conducted on online game player. Those motives can be found on every individual, simultaneously or partially. These motives also were reported to predict attitude and behavior on online gaming [18].

\section{METHOD}

\section{A. Participants}

The population on this research is game online player in Makassar. Participants were obtained by purposive sampling in 301 participants by the criteria as a student in the age betweeb13-15 year's old, active on online gaming up until now, and live in Makassar.

\section{B. Procedures}

The data were collected at two online gaming centre and three Junior High School, which located near the game center. Data were collected individually at the game centre, where the participant were given questionnaire and were explained the aim of the study, as well as providing inform consent as a prove of participants willingness to fill the questionnaire.

Data collecting at school were held classical at the class after got permission from the school. Introduction were delivered first related to the purpose of study and the confidentially of the data. Next, questionnaire was given to the participant as well as explaining about informed consent before further instruction. If the participant agrees to participate in this study, instruction on filling the questionnaire were explained and if there is any inquiry can be directly delivered to the instructor. The questionnaire then was rechecked after it was completely filled, to check on if there is no empty answer left. The type of the questionnaire is in a booklet form.

\section{Measures}

The instrument that were used in this study are two scales similar to likert 5-points scale. Both scales were adaptation scale, where the adaptation procedure is firstly asked for permission from the scale owner. Secondly, translate it into Indonesian then translate back to English (Language that were adapt). After the adaptation procedure, next is validity and reliability process on both scale. After the scale were arranged, validity and reliability test were conducted start from legibility test, content validity, until try out the test on 203 participant candidates for the construct validity and the reliability of both instrument. Construct validity were conducted by Confirmatory Factor Analysis (CFA) by using Lisrel 87 Software. Item were stated valid if the result of CFA, loading factor direction is positive and can be interpreted as the score is $>0,30$, as well as the $t$-value $>1,96$, which means it can measured a trait or a theoretical construct that is about to measure. As for the practical rules are, loadings above 0,71 excellent; >0,63-0,71very good; >0,55-0,63good; >0,450,55 fair; and >0,32-0,45poor [19]. Reliability testing by seeing the value of Cronbach's Alphaby using SPSS.

The first scale is Problematic Online Gaming Questionnaire (POGQ) which is made by Papay, et.al and were modified for this research [16]. POGQ scale consist of 12 items and were add more 12 items thus in total are 24 items. Based on the CFA result, all items were valid since the direction of loading factor is positive and can be interpreted as the value is $>0,30$, as well as $t$-value $>1,96$, which means that those 24 items are able to measure a trait or a theoretical construct that is about to measure. Next, Cronbach's Alpha value is 0,942 . It shows that those scales have a reliable measurement. 
TABLE III.1

\begin{tabular}{|c|c|c|c|c|c|}
\hline \multirow[b]{2}{*}{ Item } & \multicolumn{5}{|c|}{ CFA Result onProblematic Online GamingScale } \\
\hline & $\begin{array}{c}\text { Loading } \\
\text { Factor }\end{array}$ & Interpret & $\begin{array}{c}\text { Std. } \\
\text { Error }\end{array}$ & $t$-vale & Information \\
\hline 1 & 0,74 & Excellent & 0,07 & 10,88 & Valid item \\
\hline 2 & 0,56 & Good & 0,08 & 7,08 & Valid item \\
\hline 3 & 0,73 & Excellent & 0,07 & 10,50 & Valid item \\
\hline 4 & 0,41 & Poor & 0,08 & 5,47 & Valid item \\
\hline 5 & 0,50 & Fair & 0,07 & 6,77 & Valid item \\
\hline 6 & 0,71 & Very good & 0,07 & 10,86 & Valid item \\
\hline 7 & 0,88 & Excellent & 0,07 & 13,01 & Valid item \\
\hline 8 & 0,71 & Very good & 0,11 & 6,52 & Valid item \\
\hline 9 & 0,68 & Very good & 0,07 & 9,68 & Valid item \\
\hline 10 & 0,77 & Excellent & 0,07 & 11,17 & Valid item \\
\hline 11 & 0,43 & Poor & 0,08 & 5,02 & Valid item \\
\hline 12 & 0,77 & Excellent & 0,06 & 11,94 & Valid item \\
\hline 13 & 0,66 & Very good & 0,07 & 9,57 & Valid item \\
\hline 14 & 0,80 & Excellent & 0,09 & 9,19 & Valid item \\
\hline 15 & 0,69 & Very good & 0,07 & 9,81 & Valid item \\
\hline 16 & 0,73 & Excellent & 0,07 & 10,53 & Valid item \\
\hline 17 & 0,87 & Excellent & 0,08 & 10,86 & Valid item \\
\hline 18 & 0,84 & Excellent & 0.07 & 12,70 & Valid item \\
\hline 19 & 0,48 & Fair & 0,07 & 6,60 & Valid item \\
\hline 20 & 0,64 & Very good & 0,08 & 7,86 & Valid item \\
\hline 21 & 0,66 & Very good & 0,07 & 9,24 & Valid item \\
\hline 22 & 0,72 & Excellent & 0,07 & 10,28 & Valid item \\
\hline 23 & 0,75 & Excellent & 0,08 & 9,59 & Valid item \\
\hline 24 & 0,77 & Excellent & 0,07 & 11,24 & Valid item \\
\hline
\end{tabular}

Second scale is motive on online gaming scale, which were adapted from a scale that were made by Demetrovics et. al. Motives for Online Gaming Questionnaire (MOGQ) [8]. This scale was consisting of 7 dimensions and 27 items. Regarding to the CFA result, all items were valid because the loading factor direction is positive and can be interpreted since the value is $>0,30$, as well as the $t$-value $>1,96$, which means that these 27 items can measured the trait or theoretical construct which were about to measure. Next, the Cronbach's Alpha value is 0,941. It means that the scale has reliable measurement.
TABLE III.2

\begin{tabular}{|c|c|c|c|c|c|}
\hline \multirow[b]{2}{*}{ Item } & \multicolumn{5}{|c|}{ CFA Result on Motives for Online Gaming Scale } \\
\hline & $\begin{array}{c}\text { Loading } \\
\text { Factor }\end{array}$ & Interpret & $\begin{array}{c}\text { Std. } \\
\text { Error }\end{array}$ & $\begin{array}{c}t- \\
\text { value }\end{array}$ & Information \\
\hline 1 & 0,87 & Excellent & 0,06 & 14,91 & Valid item \\
\hline 2 & 0,51 & Fair & 0,08 & 6,67 & Valid item \\
\hline 3 & 0,74 & Excellent & 0,07 & 10,93 & Valid item \\
\hline 4 & 0,52 & Fair & 0,09 & 6,08 & Valid item \\
\hline 5 & 0,89 & Excellent & 0,07 & 12,91 & Valid item \\
\hline 6 & 0,53 & Fair & 0,07 & 7,39 & Valid item \\
\hline 7 & 0,78 & Excellent & 0,06 & 12,47 & Valid item \\
\hline 8 & 0,83 & Excellent & 0,06 & 13,73 & Valid item \\
\hline 9 & 0,78 & Excellent & 0,08 & 10,05 & Valid item \\
\hline 10 & 0,72 & Excellent & 0,07 & 10,66 & Valid item \\
\hline 11 & 0,68 & Very good & 0,08 & 8,19 & Valid item \\
\hline 12 & 0,74 & Excellent & 0,07 & 10,89 & Valid item \\
\hline 13 & 0,75 & Excellent & 0,07 & 11,14 & Valid item \\
\hline 14 & 0,89 & Excellent & 0,06 & 14,87 & Valid item \\
\hline 15 & 0,65 & Very good & 0,07 & 9,79 & Valid item \\
\hline 16 & 0,71 & Very good & 0,08 & 9,26 & Valid item \\
\hline 17 & 0,58 & Good & 0,07 & 8,17 & Valid item \\
\hline 18 & 0,60 & Good & 0.08 & 7,64 & Valid item \\
\hline 19 & 0,76 & Excellent & 0,07 & 10,20 & Valid item \\
\hline 20 & 0,87 & Excellent & 0,06 & 13,32 & Valid item \\
\hline 21 & 0,83 & Excellent & 0,06 & 13,47 & Valid item \\
\hline 22 & 0,82 & Excellent & 0,06 & 13,65 & Valid item \\
\hline 23 & 0,42 & Poor & 0,08 & 5,46 & Valid item \\
\hline 24 & 0,79 & Excellent & 0,07 & 11,98 & Valid item \\
\hline 25 & 0,69 & Very good & 0,08 & 8,46 & Valid item \\
\hline 26 & 0,63 & Good & 0,07 & 9,16 & Valid item \\
\hline 27 & 0,64 & Very good & 0,07 & 9,40 & Valid item \\
\hline
\end{tabular}

\section{RESULT}

The result of this study shows that the tendency on problematic online gaming of 301 adolescence mostly is at moderate level accounts for $64 \%$, low level about $19 \%$, and high level at $17 \%$. Boys have tendency on problematic online gaming higher than girls do.

The analysis method of this research is multiple regressions. IBM SPSS 20 for windows where use for the statistical testing. Mayor hypothesis in this study are as follow:

Ho: Motive on playing online gameis not significantly predicting the problematic online gaming use 
Ha: Motive on playing online gameis significantly predicting the problematic online gaming use

First analysis were operate by seeing the determination coefficient ( $R$ Square) which illustrate how big is the contribution of motive online gaming on problematic online gaming. Table below shows the result of the multiple regression analysis:

TABLE IV.1

\begin{tabular}{|l|c|c|c|c|}
\hline \multirow{2}{*}{ Model } & \multicolumn{4}{|c|}{ Multiple Regression Analysis Determination } \\
& $\boldsymbol{R}$ & $\boldsymbol{R}$ Square & $\begin{array}{c}\text { Adjusted } \boldsymbol{R} \\
\text { Square }\end{array}$ & $\begin{array}{c}\text { Std. } \text { Error of } \\
\text { the Estimate }\end{array}$ \\
\cline { 2 - 5 } &, 718 &, 516 &, 504 & 13,407 \\
\hline $\begin{array}{l}\text { Regres } \\
\text { sion }\end{array}$ & \multirow{2}{*}{ Soefient } \\
\hline
\end{tabular}

Tabel IV.1 shows that the value of determination coefficient ( $R$ Square) is about 0,516. It means that the predictors were simultaneously predicting problematic online gaming usefor $51,6 \%$.

The analysis that was operating next is coefficient regression testing simultaneously or $\mathrm{F}$ test by seeing the Anova table. F test were conducted to know the significant prediction of independent variable on dependent variable.

TABLE IV.2

\begin{tabular}{|l|c|c|}
\hline \multirow{2}{*}{ Model } & \multicolumn{2}{|c|}{ F Test ResultMultiple Regression Analysis } \\
\cline { 2 - 3 } & $\boldsymbol{F}$ & Sig. \\
\hline $\begin{array}{l}\text { Regres } \\
\text { sion }\end{array}$ & 44,569 &, 000 \\
\hline
\end{tabular}

Regarding to the F test table above, it was found out that $\mathrm{F}$ is accounts for 44,569 and the significant value is $p<0,05$. So, it can be concluded that every seven predictors from motive on playing online game variable simultaneously can predict problematic online gaming usevariable.

Next, statistical test also were done to test the minor hypothesis. The minor hypothesis of this research is listed below:

a. Ho $\mathrm{Ho}_{1}$ : Social motive is not significant predicting problematic online gaming use

$\mathrm{Ha}_{1}$ : Social motive is significant predicting problematic online gaming use

b. $\mathrm{Ho}_{2}$ : Escapemotive is not significant predicting problematic online gaming use

$\mathrm{Ha}_{2}$ : Escapemotive is significant predicting problematic online gaming use

c. $\mathrm{Ho}_{3}$ : Competitionmotive is not significant predicting problematic online gaming use

$\mathrm{Ha}_{3}$ : Competitionmotive is significant predicting problematic online gaming use

d. Ho $\mathrm{H}_{4}$ : Coping motive is not significant predicting problematic online gaming use

$\mathrm{Ha}_{4}$ : Coping motive is significant predicting problematic online gaming use

e. Ho5: Skill development motive is not significant predicting problematic online gaming use
Ha: Skill development motive is significant predicting problematic online gaming use

f. Ho$_{6}$ : Fantasy motive is not significant predicting problematic online gaming use

$\mathrm{Ha}_{6}$ : Fantasy motive is significant predicting problematic online gaming use

g. $\mathrm{Ho}_{7}$ : Recreation motive is not significant predicting problematic online gaming use

$\mathrm{Ha}_{7}$ : Recreation motive is significant predicting problematic online gaming use

Statistical testing was done to predict the significance on each predictor (regression coefficient testing partially) is conducted by using the result of $t$ testing of coefficient table. Below are the results of $t$ test from multiple regression analysis:

TABLE IV.3

\begin{tabular}{|c|c|c|c|c|}
\hline \multirow{2}{*}{ Predictor } & \multicolumn{4}{|c|}{ T Testing Multiple Regression Analysis Result } \\
\cline { 2 - 5 } & $\begin{array}{c}\text { Unstandardized } \\
\text { Coefficients } \\
\boldsymbol{B}\end{array}$ & $\begin{array}{c}\text { Standardized } \\
\text { Coefficients } \\
\text { Beta }\end{array}$ & $\boldsymbol{T}$ & Sig. \\
\hline (Constant) & 11,166 &, 198 & 3,420 &, 001 \\
\hline SOCIAL &, 877 &, 279 & 4,974 &, 000 \\
\hline ESCAPE & 1,474 &, 216 & 3,779 &, 000 \\
\hline COMPETITION & 1,010 &,- 030 &,- 483 &, 629 \\
\hline COPING &,- 177 &, 118 & 2,055 &, 041 \\
\hline SKILLDEV &, 571 &, 126 & 2,287 &, 023 \\
\hline FANTASY &, 595 &,- 006 &,- 106 &, 915 \\
\hline RECREATION &,- 045 & &
\end{tabular}

The table above shows the significance value of each predictor. Significance value of social is $p<0,05$, thus socialis significant predicting problematic online gaming. The second predictor, escape, has the significance value of $\mathrm{p}<0,05$, thus escape is significant predicting problematic online gaming. The third predictor, competition, has the significance value of $\mathrm{p}<0,05$, thus competitionis significant predicting problematic online gaming. Fourth predictor, coping has the significance value of $\mathrm{p}>0,05$, thus coping is not significant predicting problematic online gaming. Fifth predictor, skill development has the significance value of $\mathrm{p}<0,05$, thus skill development is significant predicting problematic online gaming. Sixth predictor, fantasy, has the significance value of $\mathrm{p}<0,05$, thus fantasy is significant predicting problematic online gaming. Seventh predictor, recreation, has the significance value of $\mathrm{p}>0,05$, thus recreationis not significantly predicting problematic online gaming.

\section{Discussion}

The problematic online gaming user is more likely to be seen in boy adolescence than girls are. Previous study also mentioned that the presentation of boy adolescence is higher 
on problematic since boys have higher addiction on video games [4] [16].

This finding found out that motive is simultaneously predicting adolescence exposure on problematic online gaming use. Previous study also mentioned that motives on using internet could predict individual exposure on internet, affinity, and satisfaction [20]. Whang, Lee, \& Chang [21]also explained that the reason or motive on using internet is an important predictor for internet addiction. Therefore, previous research can strengthen the statement that motive is able to predict behavior.

Predictors of online gaming motive if seen partially, it can be seen that five predictors can significant predict the problematic online gaming, which is social motive, escape motive, competition motive, skill development motive, and fantasy motive. While other two predictors, which is coping motive and recreation motive, is not significant predicting problematic online gaming.

The limitation of this research is the uneven sampling among the online gaming player from game centre and school. One of the sample criteria, which is actively playing online game is also not specified. The data distribution may not represent the population and affecting on the result of this research that can only applied on the research sample since it didn't use random sampling technique.

Based on the process and findings of this study, it is suggested for the further research who is interest in the same topic to find out the motive difference between adolescence who have high tendency and low tendency. It is also suggested to study on another psychological variable, which may predict those tendencies.

\section{REFERENCES}

[1] J. W. Santrock, Remaja, 11th Ed, Jilid 2, Jakarta: Erlangga, 2007.

[2] M..C. Haagsma, M. E. Pieterse, and O. Peters. "The Prevalence of Problematic Video Gamers in The Netherlands. Cyberpsychology, Behavior, and Social Networking, vol. 15, Number 3. 2012.

[3] V. Anand. "A Study of Time Management: The Correlation between Video Game Usage and Academic Performance Markers." Cyber Psychology \& Behavior, vol. 10, pp. 552-559. 2007.

[4] F. Rehbein, G. Psych, M. Kleimann, G. Mediasci, and T. Moble. "Prevalence and Risk Factors of Video Game Dependency in Adolescence: Results of a German Nationwide Survey." Cyberpsychology, Behavior, and Social Networking, vol. 13, pp. 269277. 2010.

[5] Z. Demetrovics, R. Urban, K. Nagygyorgy, J. Farkas, D. Zilahy, B. Mervo, A. Reindl, C. Agoston., A. Kertesz, and E. Harmath. "Why do You Play? The Development of The Motives for Online Gaming Questionnaire (MOGQ)." Behav Res Methods, vol. 43, pp. 814-825. 2011.
[6] E. Kuntsche, R. Knibbe, R. Engels, and G. Gmel. "Drinking Motives as Mediators of The Link between Alcohol Expectancies and Alcohol Use Among Adolescents." Journal of Studies on Alcohol and Drugs, vol. 68, pp.76-85. 2007.

[7] R. Urban, G. Kökönyei, and Z. Demetrovics. "Alcohol Outcome Expectancies and Drinking Motives Mediate The Association between Sensation Seeking and Alcohol Use Among Adolescents." Addictive Behaviors, vol. 33, pp. 1344-1325. 2008..

[8] Z. Demetrovics, R. Urban, K. Nagygyorgy, J. Farkas, M. Griffiths. O. Papay, G. Kökönyei, K. Felvinczi, and A. Olah. "The Development of the Problematic Online Gaming Questionnaire (POGQ)" PLOS ONE, vol. 7, Issue 5. 2012.

[9] S. Ak, N. Koruklu, and Y. Yilmaz. "A Study on Turkish Adolescent's Internet Use: Possible Predictors of Internet Addiction." Cyberpsychology, Behavior, and Social Networking, vol. 16, pp. 205209. 2013.

[10] S. Stieger. "Who Commits Virtual Identity Suicide? Differences in Privacy Concerns, Internet Addiction, and Personality Between Facebook Users and Quitters." Cyberpsychology, Behavior, and Social Networking. 2012.

[11] Y. Li. "Internet Addiction Among Elementary and Middle School Students in China: A Nationally Representative Sample Study." Cyberpsychology, Behavior, and Social Networking, vol. 17, pp. 111116. 2014.

[12] M. Griffiths, M. Davies, and D. Chappell, "Online Computer Gaming: A Comparison of Adolescent and Adult Gamers," Journal of Adolescence, vol. 27, pp.87-96. 2004.

[13] J. Saisan. "Internet and Computer Addiction. Signs, Symptoms, and Help for Balancing Your Time Online and Off. 2015.

[14] D. J. Kuss and M. Griffiths. "Adolescent Online Gaming Addiction." Education and Health, vol. 30. 2012.

[15] A. K. Przybylski, C. S. Riqby, and R. M. Ryan. "A Motivational Model of Video Game Engagement." Review of General Psychology, vol. 14, pp.154-166. 2010.

[16] O. Papay, R. Urban, M. Griffiths, K. Nagygyorgy, J. Farkas, G. Kokonyei, K. Felvinczi, A. Olah, Z. Elekes, and Z. Demetrovics. "Psychometric Properties of the Problematic Online Gaming Questionnaire Short-Form and Prevalence of Problematic Online Gaming in a National Sample of Adolescents." Cyberpsychology, Behavior, and Social Networking, vol. 16., 2013.

[17] O. Kiraly, R. Urban, M. Griffiths, C. Agoston, K. Nagygyorgy, G. Kokonyei, and Z. Demetrovics. "The Mediating Effect of Gaming Motivation between Psychiatric Symptoms and Problematic Online Gaming: An Online Survey" Journal of Medical Internet Research, vol. 17, pp. 1. 2015.

[18] J. Billieux, M. V. Linden, S. Achab, Y. Khazaal, L. Paraskevopoulos, D. Zullino, and G. Thorens. "Why do You Play World of Warcraft? An Indepth Exploration of Self-Reprted Motivations to Play Online and Ingame Behaviours in The Virtual World of Azeroth," Computer in Human Behavior, 2012.

[19] D. Harrington. Confirmatory Factor Analysis. New York: Oxford University Press, 2009.

[20] Z. Papacharissi and A. M. Rubin. "Predictors of Internet Use.” Journal of Broadcasting \& Electronic Media, vol. 44, pp. 175-196. 2000.

[21] L. S. Whang and G. Chang. "Internet Over-Users' Psychological Profiles: A Behavior Sampling Analysis on Internet Addiction." $\begin{array}{lllr}\text { Cyberpsychology } \& \quad \text { Behavior, } & \text { vol. } & 6 . & 2003 .\end{array}$ 